\title{
SEARCH ENGINES IN INTERNET AND INTELLECTUAL PROPERTY
}

\author{
SERGIO CÁMARA LAPUENTE \\ Profesor Titular de Derecho Civil \\ Universidad de La Rioja
}

The widespread "search engines" (buscadores) in Internet allow to track down the information scattered through the web in a very quick way and just by typing simple questions. As a general definition can serve the one offered by the référé of the Court of Great Instance of Paris of $8^{\text {th }}$ January 2001 (Cadremploi vs. Keljob; revoked by the sentence of the High Court of Paris of $25^{\text {th }}$ May 2001): "a search engine is just a device which permits to look for information through criteria given to it and should not be used to collect other things but references, contents or parts of contents in order to the immediate reutilization in the frame of a commercial enterprise, created to that aim"1.

Those instruments lack any particular regulation for the time being in the spanish legal system. Although regarding the more generic question of the liability of the renderer of services, the Bill on e-commerce, pending its tramitation in the Parliament now (May 2002), deals with the topic of search engines (art. 17) ${ }^{2}$, contrasting with the absolute silence of the EU Directive 31/2000 on e-commerce. Going further of that prelegislative text, three main questions can be formulated about the intellectual property issues related to the search engines: 1) Can the results of the searches be protected as autonomous databases?; 2) Are the search engines databases on their own?; 3) Does their operation imply an unlawful extraction and/or reuse of the information they collect from other web sites or databases or, on the contrary, is this a lawful use (right to mention)?

The answer to the first question is linked to the status granted to the creations or databases generated by computer means. The data can be presented in a "systematic or

\footnotetext{
Speaker Jean-Jacques Gómez; available in http://www.droit.technologie.org/fr/4 1.asp?jurisprudence $\mathrm{id}=54$ (my traslation). The sentence of the High Court is located in www.keljob.com/flashinfo/infoflash.jsp

Art. 17 of the Bill on e-commerce (LSSI): "los prestadores de servicios de la sociedad de la información que faciliten enlaces a otros contenidos o incluyan en los suyos directorios o instrumentos de búsqueda de contenidos no serán responsables por la información a la que dirijan a los destinatarios de sus servicios, siempre que: a) No tengan conocimiento efectivo de que la actividad o la información a la que se remiten o recomiendan es ilícita o de que puede lesionar bienes o derechos de un tercero susceptibles de indemnización, o b) si lo tienen, actúen con diligencia para suprimir o inutilizar el enlace" (text versión of the blueprint of $30^{\text {th }}$ April 2001).
} 
methodical way" (article 12 of the Spanish Intellectual Property Act ["LPI", from now on], and article 1.2 of the Directive 96/9/ECC on databases protection), and even with selection/order criteria (predetermined by the programmer or alphabetically), when separate and unarranged data spread over the whole Internet are retrieved and made individually accessible to the user. But, even if the results of the search engines are included into the notion of database, it would be necessary to solve the problem of the protection they deserve. The necessary element of the creation, as a result of a human activity, would impair the protection by means of the author's rights, since the requirement of the original creation would be missing ${ }^{3}$. But these results, and any database generated by a computer, could be protected by the sui generis right, provided that their production is the result of a material and proved investment; and for it, the value of the software necessary to generate the database and its operation would play a capital role against the rest of the resources used to obtain the final result ${ }^{4}$. Anyway, if these results are to be protected, it would be advisable to make it clear in the general terms of use of the search engine, forcing their acceptance before offering the results of the search, as well as specifying the restrictions on the reuse of the lists of links.

To solve the other two issues, it would be necessary to refine the operation of the search engines according to their typology. To remove some irrelevant cases, it would be advisable to distinguish between the local or closed search engines - which browse their own web site without violating any intellectual property right and are a system to retrieve information without skipping from one page to the other- and the general or open search engines, which make inquiries in the webs of third parties and can be thematic (within a given field) or "panthematic" (covering any field). Note the difference between the six types of general or open search engines, which could be defined as follows:

1. The directories offer the possibility to access to multiple registered web sites summarized in different categories arranged in indexes of subjects visible to the user. The web sites are reviewed by the employees of this directory who include them according to their level of interest.

3 See De Miguel Asensio, P. A., Derecho privado de internet, $2^{\text {nd }}$ ed., Civitas, Madrid, 2001, p. 230. A view against the protection via copyright based on certain human contribution can be found in Bercovitz, R., Comentarios a la Ley de Propiedad Intelectual, $2^{\text {nd }}$ ed., Tecnos, Madrid, 1997, p. 159; and FERNÁNDEZ MASIÁ, E., Informática y propiedad intelectual: software, bases de datos y creaciones asistidas por ordenador, in VV.AA, ""Los derechos de propiedad intelectual en la nueva sociedad de la información", Comares, Granada, 1998, p. 23.

See CÁMARA LAPUENTE, S., El nuevo derecho sui generis sobre las bases de datos, "Actualidad Civil", 1999,3, 18 $8^{\text {th }}-24^{\text {th }}$ January 1999, p. 83; ID., Protección jurídica de las bases de datos en Internet (Un ensayo de explicación de internet desde la normativa sobre la propiedad intelectual de las bases de datos), in CREMADES, J., FERnÁNDEZ-ORdóÑEZ, M. A., IllesCAS, R. (eds.), "Régimen Jurídico de Internet", La Ley, Madrid, 2002, p. 1567. Cfr. also CÁMARA LAPUEnTE, S., Últimas orientaciones internacionales sobre la protección jurídica de las bases de datos, in "@utor y Derecho", http://www.unirioja.es/dptos/dd/civil/autor.html.

For a more detailed of some of the categories proposed, see BROWN, M. M., BRYAN, R. M., CONLEY, J. M., Database protection in a digital world, 6 Richmond Journal of Law and Technology, 2 (Simposium 1999), available in http://www.richmond.edu/jolt/v6i1/conley.html; DARNELL, R. et al., How Search Engines Work, in http://webreference.com/dlab/books/html-pre/43-1-1-html; SuLLIVAN, D., How search engines work?, in http://www.searchenginewatch.com/webmasters/work.html. On the technical aspects and their impact on the solutions of the intellectual property, see NIPPE, W., Urheber und Datenbank. Schutz des Urhebers bei der Verwendung seiner Werke in elektronischen Datenbanken, C. H. Beck, München, pp. 49-61. 
2. The automatic search engines are software aimed at localizing, retrieving, indexing and updating the web pages on the Internet. The localization is done by means of "spiders", "robots" or "crawlers", which follow the links included in the web pages to increase continuously the information compiled. Each web page is integrated into a list of keywords using the words in the title of the web site, in its description and in the meta tags (or even in the text of the web page). The search engine offers its features to the user through a box where he/she can enter some words to request the system a list with the results following the internal index created, thus being a true database. It is also possible to offer the information in a directory or in an hybrid form.

3. The metaengines allow the user to use several search engines at the same time for a single search. Usually, they do not include their own database, rather they just forward the requests to a number of search engines, and then collect the resulting information and offer it to the user.

4. The search engines for search engines are a compilation of search engines, arranged by regions or subjects as a directory, which will also receive the question by words, and from which the user can access to the particular search involved.

5. The search services operate in a way similar to the search engines (and they even use them), but do not display immediately the results, rather they make customized inquiries according to the request and then forward the results to the user, either by email or by means of an off-line version.

The user of any of these tools usually thinks that he/she is using a "database" but, from a technological and legal point of view, according to the sources of the information received and to the search procedure, the titleholders of the intellectual property rights affected can be several (as many as databases are successfully inquired). It is possible to draw some clear conclusions from the classification offered:

- First, the pure search engines (directories or automatic search engines), provided that they fulfil the legal requirements involved (particularly the material investment, in terms of time or money) are true databases which can be at least protected by the sui generis right. The same applies to the search engines for search engines. Conversely, the search services cannot be included into this category if they do not have their own databases and just inquire the existing ones; and most of the times, the metaengines could not be included either.

- Secondly, the arrangement of the search engines as a directory can enjoy an additional protection by means of the authors' rights if the selection or arrangement criteria are original ones, since they are a collection of links which can be arranged as a database; nevertheless, their level of originality should exceed the well-known general thematic distributions used by any web site (i.e., leisure, sports, education, health, etc.).

- Thirdly, if a pure search engine or metaengine records or copies the web pages reviewed when it compiles their entries to offer them directly to the users, or if it uses the caching system (with automatic, both provisional and temporal, storage), besides of being liable for this reproduction or extraction, and in case it does not have an authorization (cfr. section 13 of the Directive 31/2000 on e-commerce; sections 14.2 and 15 of the Spanish Bill on e-commerce), it could be itself considered as database which could be protected against third parties. 
A general answer rejecting that these tools imply a violation of the intellectual property rights on the basis of the possibility that the titleholder of a work or performance on the Internet specifies that he/she does not want to become part of any index or search engine $^{6}$ (he/she would authorize it, unless otherwise provided) is not realistic or legally justified. Apart from the legal problems implied by such a unilateral provision to be legally binding, the abovementioned operation of the search engines will ignore these notices, at least as regards the automatic search engines or the metaengines. The violation of the rights would have to be considered case by case, paying attention to the criterion of the unlawful use of a third party's effort and investment (the basis of the protection granted by the sui generis right and of the rules on unfair competition) and, by way of guidelines, to the three following ones:

- The combination of the results of the search with the use of frames to offer them as their own results might imply a violation of the rights to the extraction and reuse of the creator of the database under the section 133 of the LPI.

- Since most of the web sites on the Internet are free for the users and obtain their funding from advertising, including the search engines, the skipping or removal of the advertising when they offer the information found could be a determining factor to get a court judgement. This would imply the application of the same criteria applied to the deep links?

- Sometimes, despite the appearances, these are not true search engines (which do not violate, a priori, the intellectual property rights, since they just offer the typical links to other web pages found), but real unauthorized extractions from third parties' databases ${ }^{8}$.

As regards the reference to an own web page in a search engine -a) either by the extraction of the title of the web page; b) either by means of a summary (which can be inexact or dissuasive to the users), or c) by a "framed" apparition or by means of a third party's advertising- the titleholder of the rights in this particular web page can always -at least in the cases b and c-request the removal of this reference made without his/her explicit authorization as the titleholder of the right to transformation (section 21 of the LPI; and the moral right established in the section 14.4 of the LPI). Given such a request, under the existing Spanish regulations, which are similar to the European ones as for this issue, the people responsible for the search engine could not refer to the right to mention, although most of the requirements are met (legal provision of the work, mention of the source and the author, proper use), since the essential requirement of making

\footnotetext{
Supported by SERRANO Gómez, E., La propiedad intelectual y las nuevas tecnologías, Civitas, Madrid, 2000, p. 101.

The absence of the implicit authorization of these links is based on the fact that the advertising in the homepage is removed from the referred web site, with the subsequent financial loss. The crux to determine the ad casum unlawfulness (without a general character) is the arrangement of the referred web page; particularly whether the link is misleading for the user or not, making him/her believe that what he/she is seeing is part of the referred page (this is similar to what happens with the "frames"). And even, even if such a confusion does not occur, the court could take into account the financial damage involved, considering whether the advertising can be only found in the homepage or also in the subsequent pages.

8 Cfr. the référé of the TGI of Paris, $8^{\text {th }}$ January 2001 (revoked by the Appeal Court of Paris, $25^{\text {th }}$ May 2001), cited supra.
} 
it with "critic or report purposes" is not met (article 5.3.d of Directive 29/2001/CE on copyright; and section 32 of the LPI which states that the mentions must be done "for its analysis, comment or critical judgment, and solely for education or research purposes").

Besides, it is possible to defend the same conclusion for the normal links and the search engines: the notice included by the titleholder of the intellectual property rights for the people responsible for the search engines, when the search engine enables the access to sites which clearly violate these rights, will make them responsible for the cooperation to the violation; a fact which could be more dubious if the violation is not obvious. And, anyway, it does not seem sensible to demand from the managers of any kind of search engines and metaengines to act as censors, thus impairing their functionality (based of "harvester" software); this would also imply a clear discrimination under the provisions of the Directive on e-commerce (and clearly opposed to the article 17 of the foreseen Spanish blueprint of law of transposition), since those who offer search engines would object that they receive a more severe treatment than the Internet providers, given that any of them can control the information which is reached through them ${ }^{10}$.

9 See GARROTE FERNÁNDEZ-DíEZ, I., El derecho de autor en Internet, Comares, Granada, 2001, p. 453; the same rejection of the right to mention as a defence of the links can be found in RoGEL VIDE, C., Internet y propiedad intelectual. Problemas mal resueltos o sin resolver en el Derecho comunitario al respecto, "R.G.L.J.", 2000-6, pp. p. 793. Against the defence of the rights to mention as regards the search engines, see SERRANO GÓMEZ, op. cit., p. 101; RIBAS, J., Usos permitidos en Internet, in http://www.onnet.es/01005006.

${ }_{10}$ CAMARA LAPUEnTE, Protección jurídica..., cit., p. 1585; see VerbIEST, T., Wery, E., La responsabilité des fournisseurs de services Internet: derniers développements jurisprudentiels, "Journal des Tribunaux", Bruxelles, 17 $7^{\text {th }}$ February 2001, $\mathrm{n}^{\mathrm{o}}$ 6000, pp. 170-171 (available in http://www.larcier.be/jt6000/jt 6000.pdf). 